\title{
LAPSENHUOLTOLAIN UUDISTUS JA YMMÄRRYS PERHEESTÄ
}

Sanna Koulu: OTT, tutkijatobtori, CAPS-banke, Lapin yliopisto

sanna.koulu@ulapland.fi

Janus vol. 27 (4) 2019, 413-421

JOHDANTO

Lapsioikeuden ydinkysymyksiä on perinteisesti hahmoteltu perheen, lapsen ja julkisen vallan muodostaman kolmion avulla. Perheellä on ensisijainen tehtävä lapsen kasvattamisessa, mutta julkinen valta on velvollinen turvaamaan lapsen hyvinvoinnin, jos perhe ei siihen kykene. Monissa tilanteissa joudutaankin jäsentämään perheen - ennen kaikkea vanhempien - ja julkisen vallan suhdetta, kun pohditaan lapsen asioiden järjestämistä. Vähitellen myös lapsen asemaa kolmioasetelmassa on alettu korostaa: lapsi ei ole vain ratkaisujen tai toiminnan kohde, vaan myös oikeuksien subjekti. ${ }^{1}$

Vuoden 2018 syksyllä kolmion linjoja jäsennettiin uusiksi, kun lapsen huollosta ja tapaamisoikeudesta annettuun lakiin (361/1983) tehtiin mittava uudistus. Vuodelta 1983 oleva laki on kestänyt hyvin aikaa, mistä lienee kiittäminen niin tuolloisen lainsäädäntötyön periaatelähtöistä harkintaa kuin lain joustavaa normistoakin. Sekä yhteiskunnassa että perheiden arjessa on silti tapahtunut muutoksia, joita tuolloinen lainsäätäjä ei voinut ennakoida. Lainsäädäntöuudistus oli tarpeen sekä hallitusohjelman toteuttamiseksi että oikeuskäytännössä tapahtuneen kehityksen kodifioimiseksi ja selkiyttämi- seksi (ks. valmistelusta mm. OMML 47/2017, 7-8).

Vuoden 1983 lain kestävyys lienee vaikuttanut nyt valittuun lainsäädäntötekniikkaan. Uudistushanke toteutettiin nimittäin teknisesti muuttamalla aiempaa lakia ja lisäämällä sen säännösten väliin uusia pykäliä sen sijaan, että olisi säädetty uusi laki kuten isyyslain ja adoptiolain uudistuksissa. Ratkaisua voidaan kritisoida siitä, että se johti hajanaisuuteen lain logiikassa, mikä tekee lakitekstistä paikoin vaikeaselkoista. Lakitekstissä luvataan paljon hyvää ja kaunista, mutta säännösten konkreettinen soveltaminen voi osoittautua vaikeammaksi kuin voisi toivoa.

Uudistuksen taustalla ovat pitkälti samat periaatteet kuin jo vuoden 1983 laissa: huoltajien yhteistoiminnallisuus, lapsen osallisuuden merkitys, sopimusten ja sovinnollisuuden etusija, ja täytäntöönpanokelpoisten ja käytännössä toteutuvien ratkaisujen tavoittelu. Uudistus vahvistaa näitä periaatteita entisestään. Esimerkiksi jo aiemmin etusijalle asetettu vanhempien sopimuksellisuus saa entistä korostuneemman merkityksen, kun lastenvalvojan luona tehtävien sopimusten sisällöllinen liikkumavara kasvaa.

Tässä puheenvuorossa arvioin uudistusta tarkastellakseni, millaisia ymmär- 
ryksiä perheestä ja lasten asemasta siihen sisältyy. Selostan lyhyesti keskeiset muutokset, ja pohdin sen jälkeen $\mathrm{Ca}-$ rol Bacchin (Bacchi 2009; Bacchi \& Goodwin 2013) hahmotteleman ongelmanasetteluiden analyysin avulla, millaisina perheeseen ja lasten asemaan liittyvät ongelmat uudistuksessa nähdään. Ongelmanasettelujen tarkastelu tarjoaa hedelmällisen näkökulman lain tekstipinnan alla risteäviin jännitteisiin ja ristiriitoihin.

\section{MIKÄ LAISSA MUUTTUI?}

Uudistustyön lopputuloksena lapsen huollosta ja tapaamisoikeudesta annettu laki sai 15 uutta ja 18 ainakin osittain muutettua pykälää. Lisäksi uudistuksessa tehtiin pienempiä muutoksia muuhun sääntelyyn - olennaisimmin lapsen huoltoa ja tapaamisoikeutta koskevan päätöksen täytäntöönpanosta annettuun lakiin (619/1996).

Hallituksen esityksessä uudistuksen tavoitteet kuvataan tiiviisti:

"Esityksen keskeisin tavoite on parantaa lapsen edun toteutumista lapsen huoltoa ja tapaamisoikeutta koskevissa asioissa. Tavoitteena on myös saattaa lapsenhuoltolaki ajan tasalle siten, että se vastaa yhteiskunnassa tapahtuneita muutoksia ja oikeuskäytäntöä. Lisäksi ehdotuksella pyritään vahvistamaan lapsen osallisuutta häntä koskevien asioiden käsittelyssä ja tehostamaan lapsen huoltoon ja tapaamisoikeuteen liittyvien asioiden oikeuskäsittelyä. Esityksessä ei ehdoteta muutoksia kansainvälisen yksityisoikeuden alaa koskeviin säännöksiin eikä vieraassa valtiossa annetun päätöksen vahvistamista tai lapsen palauttamista koskevaan menettelyyn." (HE 88/2018 vp, 18)

Kappaleessa uudistukselle asetetaan neljä olennaista tavoitetta. Kaksi ensimmäistä tavoitetta, eli parannukset lapsen edun toteutumiseen sekä lain saattaminen ajan tasalle yhteiskunnallisten muutosten ja oikeuskäytännön kanssa, on muotoiltu varsin ympäripyöreästi, kun taas kaksi jälkimmäistä tavoitetta, lapsen osallisuuden vahvistaminen ja menettelyn tehostaminen, liitetään jaksossa olennaisesti huoltoa ja tapaamisoikeutta koskevien asioiden viranomaiskäsittelyyn. Monet lain periaatteellisesti merkittävimmistä uudistuksista liittyvät nimenomaan kahteen ensimmäiseen tavoitteeseen. Uudistuksessa tunnistetaan vuoroasuminen ratkaisuna lapsen asumisesta, laajennetaan huoltoa ja tapaamisoikeutta koskevien sopimusten alaa, tarjotaan mahdollisuus lapsen ja muun henkilön kuin vanhemman väliselle tapaamisoikeudelle, ja tuodaan lakiin uudistuksia vieraannuttamisen ja muun tapaamisoikeuden estämisen ehkäisemiseksi (HE 88/2018 vp, 20-22). Tavoitteisiin sisältyy myös oikeuskäytännössä omaksuttuja parannuksia, jotka nyt kirjataan lakiin. Esimerkiksi mahdollisuus tietojensaantioikeudesta sopimiseen, tapaamiskustannusten jakamiseen sekä tuettuja tai valvottuja tapaamisia koskeviin määräyksiin perustuvat kaikki vakiintuneeseen - tosin osin alueelliseen - käytäntöön.

Tavoitteet lapsen osallisuuden vahvistamisesta ja menettelyn tehostamisesta kietoutuvat osin toisiinsa. Lapsen osallisuuden toteuttaminen on nimittäin paljolti menettelyllinen kysymys, sillä lapsella ei uudistuksen jälkeenkään ole itsenäistä asianosaisasemaa huolto- tai 
tapaamisasiassa (ks. HE 88/2018 vp, 9 ja KKO 2012:95). Hallituksen esityksessä parannukset on muotoiltu muun muassa huoltajien, lastenvalvojan ja tuomioistuimen tehtävien muutoksina. Lapsen osallisuus pyritään huomioimaan nykyistä paremmin riippumatta käsittelyn muodosta tai vaiheesta. Varsinaisina menettelyllisinä uudistuksina tuodaan esiin olosuhdeselvitysten hankkimisen jäntevöittäminen ja selvitystyön nopeuttaminen, käsittelyn joutuisuuden parantaminen ja toistuvien oikeudenkäyntien ehkäiseminen.

Uudistetussa laissa vuoroasumista koskevat säännökset on sisällytetty muutettuihin 7 ja 9 S:iin, joihin se lisättiin yhtenä mahdollisena vaihtoehtona sopimuksen tai tuomioistuimen ratkaisun sisällöksi. Lisäksi vuoroasuminen mainitaan uusissa 7 b ja 9 a $:$ :issä, joiden mukaan sopimuksessa tai ratkaisussa tulee määrätä vuoroasumisen ja tapaamisoikeuden tarkemmista ehdoista sekä siitä, kumpi koti ilmoitetaan lapsen viralliseksi asuinpaikaksi. Sopimuksessa tai ratkaisussa voidaan lisäksi määrätä vuoroasumisen tai tapaamisoikeuden toteuttamisesta aiheutuvista kuljetuksista tai matkakuluista. ${ }^{2}$

Siinä missä vuoroasumisesta voidaan määrätä joko sopimuksella tai tuomioistuimen ratkaisulla, lapsen tapaamisoikeus muuhun henkilöön kuin vanhempaan on yksinomaan tuomioistuinasia. Alkuperäinen työryhmämietintö ehdotti sopimusmahdollisuutta myös tällaisen tapaamisoikeuden osalta, mutta mahdollisuus jäi pois jatkovalmistelussa monien lausunnonantajien kannoista huolimatta. Uudistuksessa näkyykin jännite perheen ja julkisen vallan välisessä työnjaossa, kun ydinperheen rajat ylittäviin ratkaisuihin edellytetään valtion tuomiovallan tukea. Lopputulos hämmentää, sillä sopimuksella voidaan uudistetun 7 \:n mukaan määrätä sekä oheishuoltajuudesta että lapsen asumisesta oheishuoltajan luona - ratkaisu, joka menee pidemmälle kuin pelkkä tapaamisoikeus menisi.

Voimaan tulevan 9 c $\$$ :n mukaan lapselle voidaan vahvistaa oikeus tavata "hänelle erityisen läheistä henkilöä, jonka kanssa hänellä on lapsen ja vanhemman väliseen suhteeseen verrattava vakiintunut suhde". Tapaamisoikeus vahvistetaan aina tuomioistuimen päätöksellä, mutta muutoin siihen "sovelletaan, mitä lapsen ja vanhemman välisestä tapaamisoikeudesta säädetään”. Lapsen ja muun henkilön kuin vanhemman tapaamisoikeuteen viitataankin useissa muissa pykälissä, joten kokonaisuus on hieman vaikeaselkoinen.

Vieraannuttamista ja tapaamisoikeuden estämistä koskevat muutokset on samoin siroteltu eri puolille lakia. Tapaamisoikeutta koskevan 2 \$:n muutetussa 2 momentissa määrätään, että lapsen kummankin "vanhemman on omalta osaltaan myötävaikutettava tapaamisoikeuden toteutumiseen. Vanhemman on kasvatustehtävässään vältettävä kaikkea, mikä on omiaan aiheuttamaan haittaa lapsen ja toisen vanhemman väliselle suhteelle." Lakiin on myös sisällytetty säännös velvollisuudesta ilmoittaa toiselle vanhemmalle aiotusta muutosta, jos muuttamisella olisi vaikutusta huollon tai tapaamisoikeuden toteuttamiseen (uusi 5 a ), ja "tapaamisoikeuden turvaamisesta" määräämällä uhkasakon asettamisesta jo alkuperäisen tapaamisratkaisun yhteydessä (uusi $9 \mathrm{~d} \$$ ). ${ }^{3}$ 
SÄÄNTELYASIAKIRJOJEN KRIITTINEN LUKEMINEN

Kuten usein lainsäädäntöprosesseissa, myös lapsenhuoltolain uudistus on tasapainottelua eri tavoitteiden välillä. Kompromissit ovat ehkä tavallista huomaamattomampia, sillä uudistuksen tarpeesta ja päälinjoista vallitsi laaja yksimielisyys. Pinnan alla on kuitenkin havaittavissa jännitteitä: perheitä koskevat hahmotukset ja lapsen edun tulkinnat risteävät keskenään. Vaikka oikeustiede on perinteisesti keskittynyt lain säännösten tulkintaan ja oikeuden eheyden tuottamiseen - muun muassa lain tavoitteiden analyysillä - tämän kaltaisten jännitteiden tutkiminen on tullut osaksi oikeustieteen valtavirtaa. Oikeustieteessä onkin enenevässä määrin hyödynnetty muiden yhteiskuntaja ihmistieteiden menetelmiä oikeudellisten tekstien tutkimisessa (ks. Koulu 2014, 221-227).

Erään mahdollisen työkalun sääntelyn jännitteiden analysoimiseen tarjoaa australialaisen politiikan tutkijan Carol Bacchin (2009) poststructural policy analysis, suomeksi vaikkapa poststrukturaalinen poliittisten linjausten analyysi. Bacchi ehdottaa analyysin apuvälineeksi strategiaa, jossa politiikan tekstejä ja käytäntöjä luetaan sen valossa, millaisena niissä kuvataan ratkaistavat ongelmat ("What's the Problem Represented to be" tai WPR-lähestymistapa) (Bacchi \& Goodwin 2016, 13). Lainsäädäntöasiakirjoihin sisältyy aina enemmän tai vähemmän näkyvästi tulkintoja siitä, mitä ongelmia lainsäädännöllä on tarkoitus ratkaista, ja siten myös siitä, millaisia nuo ongelmat ovat ja millaiset ratkaisut ovat mahdollisia. Keskeinen osa analyysiä on ottaa tekstissä tarjotut rat- kaisut ja lähteä niiden avulla paikantamaan ongelmia ja niiden taustaoletuksia. Bacchin muotoilema lähestymistapa auttaa siten jäsentämään lapsenhuoltolain uudistuksen lähtökohtaista yksimielisyyttä monisyisemmin. Lapsen etua ja perheiden hyvinvointia koskevan konsensuksen taustalla on erotettavissa erilaisia arvioita siitä, millaiset riskit niitä uhkaavat ja millaisia ongelmia nyt voimaantulevalla sääntelyllä siten ratkaistaan.

\section{UUDISTUSTYÖSSÄ ASETELLUT ONGELMAT}

Tässä jaksossa tarkastelen ongelmanasetteluja muutamassa lapsenhuoltolain keskeisistä muutoksista. Nostan esiin neljä merkittävää teemaa: vuoroasumisen, lapsen ja muun henkilön kuin vanhemman tapaamisoikeuden, vieraannuttamisen ja lapsen suojaamisen väkivallalta. Linjausta puoltavat muun muassa lain uudistuksesta tiedottaminen sekä lainsäädäntöprosessissa esitetyt huomiot (esim. Oikeusministeriö 2019; EV 175/2018 vp). Analyysissä jätän vähemmälle huomiolle lapsen osallisuuden parantamisen, menettelyn tehostamisen ja sopimusten käyttöalan lisäämisen, jotka eivät liity niin kiinteästi perheiden hahmotustapoihin.

\section{Vuoroasuminen}

Vuoroasumista koskevassa uudistuksessa tavoitteena on "[tehdä] näkyväksi järjestely, jossa lapsi asuu tosiasiassa vuorotellen kummankin vanhempansa luona yhtä paljon tai lähes yhtä paljon" (HE 88/2018 vp, 20). Ongelma kuvataan siten ennen kaikkea lainsäädännön tarjoamien mahdollisuuksien ja "tosielämän" välisenä ristiriitana: laki 
ei tuo näkyväksi tosiasiallista tilannetta. Tämä hahmotus lainsäädännön tarkoituksesta on perheoikeudelle ominainen (mm. HE 37/2010 vp, 12-15), ja se toistuu myös monissa sukupuolineutraalia avioliittolakia ja äitiyslakia koskevissa keskusteluissa. ${ }^{4}$ Taustalla lienee havaittavissa tietynlainen hyvinvointivaltiollisuus: ongelmanasettelu heijastaa ajatusta, jossa lain ja todellisuuden on mahdollista ja jopa suotavaa olla keskenään sopusoinnussa.

Vuoroasumista koskevan lainsäädännön ja tosielämän välinen vastaavuussuhde on kuitenkin rajallinen. Vuoroasumisella tarkoitetaan "lähtökohtaisesti tilannetta, jossa lapsi asuu vähintään 40 prosenttia kalenterivuodesta toisen vanhempansa luona”. Tätä epäsuhtaisemmat vuoroasumistilanteet jäsennetään esityksen mukaan edelleen tapaamisoikeuden käsitteellä.Vuoroasuminen ei liioin muuta sitä lähtökohtaa, että lapsella voi olla vain yksi virallinen asuinpaikka. Tavoiteltu vastaavuus sääntelyn ja tosielämän välillä ei siten koske kaikkia perheitä ja lapsia, vaikka lainsäädännön kattavuus paraneekin aiemmasta.

\section{Lapsen ja muun kuin vanhemman tapaa-} misoikeus

Eräs lain keskustelluimmista uudistuksista on mahdollisuus vahvistaa lapselle täytäntöönpanokelpoinen oikeus tavata muuta hänelle erityisen läheistä henkilöä kuin vanhempaa. Hallituksen esityksen mukaan uudella säännöksellä "toteutetaan Euroopan ihmisoikeussopimuksen perhe-elämän suojaa koskevan 8 artiklan velvoitetta ja saatetaan lainsäädäntö sopusointuun Euroopan ihmisoikeustuomioistuimen ratkaisu- käytännön kanssa". Ongelmana esitetään lain eroavuus voimassaolevista ihmisoikeussopimuksista. Eroavuus näyttäytyy kuitenkin huomattavan neutraalina, ja rivien välissä voitaneen erottaa ajatus lainsäädännön jäämisestä ihmisoikeuskäytännöstä jälkeen. Lainsäädännön ja ihmisoikeuskäytännön saattaminen sopusointuun hahmottuu paremminkin teknisenä kuin oikeuspoliittisena ratkaisuna. ${ }^{5}$

Oikeuspoliittinen ulottuvuus on ollut selvemmin läsnä uudistustyötä koskevissa lausunnoissa (OMML 13/2018, 30-32) ja yleisökeskustelussa. Mahdollisuus vahvistaa oikeudellisesti sitovalla tavalla tapaamisoikeus muuhun kuin vanhempaan on liitetty muun muassa isovanhempien asemaan sekä sateenkaariperheiden tarpeisiin varmistaa lapsen oikeus pitää yhteyttä kaikkiin vanhempiinsa. Samoin työryhmämietinnön ja hallituksen esityksen kuvaama Euroopan ihmisoikeustuomioistuimen käytäntö heijastaa perustavampaa tapaa hahmottaa samaa kysymystä: kysymyksessähän on perhe-elämän suojan ulottuvuus ja sen määrittäminen vaihtuvissa perhetilanteissa.

\section{Vieraannuttaminen ja tapaamisoikeuden estäminen}

Lapsen huoltoa ja tapaamisoikeutta koskeva sääntely on vuodesta 1983 lukien lähtenyt ajatuksesta, että vanhempien ja huoltajien tulee toimia yhdessä lapsen edun turvaamiseksi (mm. Savolainen 1984, 134). Lain uudistuksessa tämä perusajatus on puettu uuteen muotoon, kun siihen on liitetty nimenomainen tavoite ehkäistä "vieraannuttamista ja tapaamisoikeuden estämistä". Hallituksen esityksen mukaan laissa 
tulisi huomioida "vanhemman kyky asettaa lapsen tarpeet vanhempien välisten ristiriitojen edelle", ja "ratkaisua tehtäessä olisi kiinnitettävä huomiota muun ohella siihen, mikä ratkaisu voisi parhaiten turvata lapsen ja vanhemman välisen suhteen säilymisen" (HE 88/2018 vp, 22). Ongelma esitetään vanhemman kykenemättömyytenä asettaa lapsen tarpeet ristiriitojen edelle, ja siksi sen nähdään edellyttävän julkisen vallan puuttumista. Vanhempien keskinäisen suhteen ristiriidat hahmottuvat sivuseikkana eivätkä ne vaikuta lapsen etuun. Lapsen etu samastuu hyvin vahvasti lapsen ja vanhemman välisen suhteen säilymiseen.

Esityksessä jatketaan, että tapaamisten estämistilanteita tulisi ennaltaehkäistä perhettä tukevilla sosiaalitoimen toimenpiteillä, ja että "[v]aikeiden tapausten taustalla olevien syiden selvittäminen edellyttää moniammatillista asiantuntemusta”. Tämä viranomaisten toimintaa ja palveluverkostoa koskeva osio toistaa samaa ongelmanasettelua: vaikeissa tapauksissa on käsillä jokin vanhempien puute tai vaillinaisuus tai muu lapsen hyvinvointiin liittymätön syy, joka on kuitenkin pohjimmiltaan selvitettävissä tai ratkaistavissa. Ongelmanasettelu ei jätä tilaa mahdollisuudelle, että perheessä olisi ratkaisemattomia tai lapselle haitallisia konflikteja tai väkivaltaa. Mahdolliset konfliktit hahmottuvat nimenomaan vanhempien välisinä ristiriitoina eikä niillä nähdä olevan vaikutuksia lapseen. ${ }^{6}$

\section{Lapsen suojaaminen väkivallalta}

Lapsen suojaaminen väkivallalta ja muulta kaltoinkohtelulta on huomioitu jo hallituksen esityksessä, mutta se ko- rostui entisestään eduskuntakäsittelyn aikana. Hallituksen esityksessä todetaan keskeisenä ehdotuksena, että säännöksiä täsmennettäisiin "säätämällä huoltajien velvollisuudeksi suojella lasta kaikenlaiselta ruumiilliselta ja henkiseltä väkivallalta, huonolta kohtelulta ja hyväksikäytöltä”. Ehdotus yhdistetään yhtäältä YK:n lapsen oikeuksien sopimuksen, toisaalta ns. Istanbulin sopimuksen velvoitteisiin. Hallituksen esityksessä lapsen suojeleminen väkivallalta sisällytettiin huollon tavoitetta ilmaisevaan, periaateluontoiseen 1 『:ään.

Eduskuntakäsittelyssä väkivaltaa arvioitiin perusteellisemmin kuin hallituksen esityksessä. Lakivaliokunta päätyi esittämään väkivallalta suojaamisen lisäämistä myös 10 \:ään, jossa säädetään asian ratkaisuperusteista (LaVM 12/2018 vp, 5). Lapsen suojaaminen väkivallalta tulisi huomioitavaksi ratkaisuperusteena jo muutettavan 1.2 §:n nojalla, mutta "asian tärkeyden vuoksi" maininta oli syytä sisällyttää myös 10 §:n luetteloon. Valiokunnan ehdotus korostaa siten sosiaalitoimen ja tuomioistuimen velvollisuutta huomioida mahdollinen väkivalta aina, kun ne arvioivat lapsen etua eri ratkaisuvaihtoehdoissa. Valiokunta huomauttaa muun muassa, että valvottuja ja tuettuja tapaamisia koskeva säännös auttaa varmistamaan, "ettei tapaamis- tai huoltajuusoikeuksien käyttäminen vaaranna perheväkivallan uhrin tai lasten oikeuksia ja turvallisuutta". Samalla on "tärkeää, että perheessä esiintynyt väkivalta tunnistetaan käytännössä" ja että "mahdolliseen väkivaltaan kiinnitetään huomiota sosiaalitoimen tehdessä tuomioistuimelle olosuhdeselvitystä perheen tilanteesta. Väkivallan tunnistaminen on tarpeen 
huomioida myös sosiaalitoimen ja tuomareiden koulutuksessa".

Ongelmanasettelu muuttuu näin hallituksen esityksen ja lakivaliokunnan mietinnön välillä. Siinä missä hallituksen esityksessä säännös lapsen suojaamisesta väkivallalta hahmotetaan teknisenä "täsmentämisenä" ihmisoikeusvelvoitteiden vuoksi, lakivaliokunnan mietinnössä väkivalta on jotain tosiasiallista ja tärkeää, joskin välillä vaikeasti tunnistettavaa. ${ }^{7}$ Valiokunnan mietinnössä tunnistetaan ainakin jollain tasolla myös, että vanhempaankin kohdistunut tai "perheessä esiintynyt" väkivalta voi vaikuttaa lapseen. Ongelma piirtyy ennen kaikkea julkisen vallan ja palveluverkoston vastuunkantona lapsen tilanteesta, ja oletuksena on, että väkivallan tunnistaminen ja huomioiminen paranevat koulutuksella ja hyvillä käytännöillä.

\section{Perheitä ja lapsuuksia}

Lapsenhuoltolain uudistustyön tarkastelu paljastaa varsin ristiriitaisia hahmotuksia perheiden ja lasten tilanteista. Yhtäältä uudistuksessa painotetaan yhteistoiminnallisuutta ja molempien vanhempien merkitystä lapsen kannalta, toisaalta viitataan perheiden moninaisuuden huomioimiseen sekä siihen, kuinka tärkeää lainsäädännön on huomioida elävää elämää. Uudistuksessa piirretyt perheiden kuvat ovat keskenään yhteismitattomia. Samoissa säännöksissä viitataan sekä vieraannuttamisen vaarallisuuteen että väkivallan huomioimisen tärkeyteen, mutta mahdollisen väkivallan merkitystä lapsen ja etävanhemman suhteen riskinä tai haasteena ei lakitekstissä huomioida mitenkään.

Kuten Bacchi toteaa, tekstit eivät tyypillisesti tyhjenny yhteen lukukierrokseen, vaan ongelmanasetteluihin paneutuminen on omiaan paljastamaan uusia, sisäkkäisiä ongelman kuvauksia. Ongelmanasettelut viittaavat usein eri suuntiin, sillä lainsäädäntötekstit ovat monien muiden poliittisten ehdotusten tavoin kompromissien tulosta. Olen tässä keskittynyt sisällöllisesti olennaisimpiin muutoksiin, ja puheenvuorossa jäävät siten syrjään oikeudenkäyntien tehostamiseen ja sosiaalipalveluiden järjestämiseen liittyvät ehdotukset. Niiden tutkiminen voisi tarjota hedelmällisiä lähestymistapoja perheiden hallinnan ja erityisesti perhe- ja lapsioikeuden rationaliteettien hahmottamiseen.

Puheenvuoron tavoitteena on ollut eritellä varovasti uudistuksen pinnan alla häivähtäviä jännitteitä ja ristiriitoja. Uudistuksen voi ennakoida - ainakin näin ennen sen voimaantuloa - tuovan aitoja parannuksia monien perheiden tilanteisiin sekä lapsen aseman huomioimiseen. Erityisesti uudistettu laki lienee omiaan parantamaan sovinnollisten perheiden asemaa. Sovinnollisten perheiden tilanne oli toki jo varsin hyvä ennen uudistusta, sillä laki on 1983 lukien mahdollistanut varsin laajan tilan sopimiselle (vrt. Wickström 1998, 30). Haasteena onkin, miten uudistuksen toimeenpanossa huomioidaan perheiden moninaisuus ja kunkin lapsen yksilöllinen etu niissä tilanteissa, joissa julkiselta vallalta edellytetään pidemmälle menevää perheen tilanteen arvioimista kuin mikä on välttämättä mahdollista sopimusta vahvistettaessa. 
Lakiuudistuksen ongelmanasetteluissa ongelmien ratkaisua haetaan monesti eropalveluista, moniammatillisesta asiantuntemuksesta tai sosiaalitoimen ja tuomarien koulutuksesta. Perheen, lapsen ja julkisen vallan muodostama kolmio ei ole tasasivuinen. Vanhempien konflikteja jäsennetään joko parisuhderistiriitojen tai kaltoinkohtelun ja väkivallan termein. Sen sijaan lapsen rooli jää - osallisuuden korostamisesta huolimatta - tekstissä etäiseksi, ja julkisten toimijoiden asiantuntemukselle ja osaamiselle asetetaan yhä enemmän painoa.

\section{ViITTEET}

1 Muutos heijastaa ennen kaikkea YK:n lapsen oikeuksien sopimusta, joka ratifioitiin Suomessa vuonna 1991 ja joka on keskiössä ns. modernissa lapsioikeudessa (ks. Hakalehto-Wainio 2013).

2 Mahdollisuus matkakulujen jakamiseen on huomioitu jo korkeimman oikeuden ratkaisussa KKO 2003:66. Kysymys ei ole juridisesti aivan helppo, sillä tapaamisoikeuden toteuttamiseen liittyviä kuluja ei voida kokonaan irrottaa lapsen elatuksesta. Korkein oikeus toteaakin ratkaisussaan, että "päätettäessä tapaamiskustannuksia koskevasta vastuusta on perusteltua noudattaa soveltuvin osin lapsen elatuksesta annetun lain säännöksistä ilmeneviä periaatteita siitäkin syystä, että nyt kysymyksessä olevia matkakuluja voidaan pitää sellaisina kustannuksina, jotka tuon lain 1 \:n mukaan kuuluvat lapsen elatukseen ja jotka siten voitaisiin harkinnan mukaan ottaa huomioon elatusavun määrää vahvistettaessa."

3 Mainittu 9 d §:n säännös on merkittävä, sillä se liudentaa ns. perusteratkaisun, eli alkuperäisen sisällöllisen ratkaisun, ja myöhemmän täytäntöönpanoratkaisun rajaa. Hallituksen esitys on suhteellisen niukkasanainen muutoksesta; ks. HE 88/2018 vp, 22, 55-56.

4 Ks. esim. LaVM 1/2018 vp, 5: "Säännös ei tunnista tilannetta, jossa hedelmöityshoi- toa annetaan kahden naisen muodostamalle parille, mutta aloitteesta ilmenee, että ilmiö on käytännössä hyvin yleinen" (korostus tässä). 5 Muotoilu on kiinnostava muun muassa siksi, että Euroopan ihmisoikeussopimuksen 8 artiklan vaatimukset eivät tähän mennessä liene olleet yhtä yksiselitteisiä kuin katkelma antaisi ymmärtää. Tapaamisoikeuden vahvistaminen ja täytäntöönpano hahmotetaan yleensä ennemminkin valtion positiivisen toimintavelvoitteen toteuttamisena, ja ihmisoikeustuomioistuin on ollut verrattain varovainen ulottamaan positiivisen toimintavelvoitteen piirin muihin henkilöihin kuin vanhempiin. Vrt. esim. Schneider v. Saksa 15.9.2011.

6 Ks. tästä ajattelumallista oikeudellisissa teksteissä myös Hautanen 2010, 173-175.

7 Väkivallan eri muotojen tunnistamista on korostettu myös THL:n koordinoimassa tavoite- ja toimenpideohjelmassa lapsiin ja nuoriin kohdistuvan väkivallan ehkäisemiseksi; ks. https://thl.fi/fi/ tutkimus-ja-kehittaminen/tutkimukset-jahankkeet/kansallinen-lasten-ja-nuortenturvallisuuden-edistamisen-ohjelma (luettu 8.10.2019). Ks. keinoista myös Karhuvaara ym. 2013.

\section{KirJallisuUs}

Bacchi, Carol (2009) Analysing Policy: What's the Problem Represented to be? Frenchs Forest: Pearson Education.

Bacchi, Carol Lee \& Goodwin, Susan (2016) Poststructural Policy Analysis - A Guide to Practice. Basingstoke: Palgrave Macmillan. https://doi.org/10.1017/ s0047279418000648

Hakalehto-Wainio, Suvianna (2013) Uusi lapsioikeus. Teoksessa Jaakko Husa, Petri Keskitalo, Tuula Linna \& Eva TammiSalminen (toim.) Oikeuden avantgarde. Juhlajulkaisu Juha Karhu. Helsinki: Talentum, 59-76.

Hautanen, Teija (2010) Väkivalta ja huoltoriidat. Tampere: Tampere University Press.

HE 37/2010 vp. Hallituksen esitys Eduskunnalle laeiksi avopuolisoiden yhteistalouden purkamisesta ja eräiden siihen 
liittyvien lakien muuttamisesta

HE 88/2018 vp. Hallituksen esitys eduskunnalle laiksi lapsen huollosta ja tapaamisoikeudesta annetun lain muuttamisesta ja eräiksi siihen liittyviksi laeiksi.

Karhuvaara, Marjatta \& Kaitue, Sanna \& Ruuhilahti, Susanna (2013) Lähisuhdeväkivallan kartoittaminen ja siihen puuttuminen lastenvalvojan työssä. Helsinki: THL.

Koulu, Sanna (2014) Lapsen huolto- ja tapaamissopimukset. Oikeuden rakenteet ja sopivat perheet. Helsinki: Lakimiesliiton kustannus.

LaVM 1/2018 vp.Valiokunnan mietintö.

LaVM 12/2018 vp.Valiokunnan mietintö.

Oikeusministeriö (2019) Oikeusministeriön tiedote 7.2.2019. https://oikeusministerio.fi/artikkeli/-/asset_publisher/ lapsenhuoltolakiin-uudistuksia-joulukuun-alusta-lukien Luettu 27.8.2019.
OMML 47/2017. Lapsenhuoltolain uudistaminen. Työryhmän mietintö. Oikeusministeriön mietintöjä ja lausuntoja 47/2017.

OMML 13/2018. Lapsenhuoltolain uudistus. Lausuntotiivistelmä työryhmämietinnöstä. Oikeusministeriön mietintöjä ja lausuntoja 12/2018.

Savolainen, Matti (1984) Lapsen huolto ja tapaamisoikeus. Helsinki: Suomen lakimiesliiton kustannus.

Wickström, Anita (1998) 1998 års vårdnadsreform och socialtjänsten. Stockholm: Norstedts juridik. 